\title{
Statyba
}

\section{CONCENTRATIONS OF INDOOR AND SOIL RADON IN LITHUANIA}

\section{K. Gasiūnas PhD (deceased) , A. Mastauskas \& G. Morkūnas}

To cite this article: K. Gasiūnas PhD (deceased) , A. Mastauskas \& G. Morkūnas (1998)

CONCENTRATIONS OF INDOOR AND SOIL RADON IN LITHUANIA, Statyba, 4:4, 316-321, DOI:

10.1080/13921525.1998.10531424

To link to this article: https://doi.org/10.1080/13921525.1998.10531424

曲 Published online: 26 Jul 2012.

Submit your article to this journal $\pi$

Џ Article views: 78 


\title{
RADONAS GRUNTO ORE IR PATALPOSE LIETUVOJE
}

\author{
K. Gasiūnas, A. Mastauskas, G. Morkūnas
}

\section{1. İvadas}

Natūralios kilmès radionuklido radono efektinès dozès patalpose kai kuriais atvejais siekia net šimtus milisivertų. Todèl, norint sumažinti radono neigiamą poveiki žmogaus sveikatai, bütina nustatyti, kaip jis patenka i pastato vidu ir kaupiasi jame. Tuomet jau galima prognozuoti, kokie radono tūriniai aktyvumai bus statomuose pastatuose dar tik parenkant šił pastatụ statybvietes.

\section{Tyrimų tikslas}

Radiacinès saugos centras, padedamas Švedijos radiacinès saugos instituto, nuo 1995 metų Lietuvoje atlieka plataus masto tyrimus, kuriu metu atliekami radono tūrinių aktyvumų matavimai patalpose ir grunto ore. Gauti duomenys suteikia informacijos apie vidutinius radono tūrinius aktyvumus šalyje ir šalies regionuose, kuriuose šie aktyvumai turi tendenciją būti aukštesni už šalies vidurkị, bei apie galimus būdus numatyti radono tūrinius aktyvumus statomuose pastatuose, kad būtụ galima sumažinti gyventojų apšvitos dozes.

\section{Objektas}

Radonas yra radioaktyvusis periodinès elementy sistemos VIII grupès cheminis elementas, inertinès dujos, kuriu atominis skaičius yra 86. Gamtoje sutinkami trys radono izotopai: Rn-219, arba aktinonas, (pusèjimo trukmè 3,92 s), Rn-220, arba toronas, (54,5 s) ir Rn-222, arba radonas, (3,82 dienos). Iš visu radono izotopỵ patalpose būna tik $\mathrm{Rn}$-222 didesni kiekiai. Kiti du radono izotopai dẻl savo trumpaamžišskumo suskyla nepasiekę patalpų vidaus. Nustatyta [1], kad torono sąlygota kolektyvinè žmonijos dozè sudaro tik $2-10 \%$ radono sąlygotos dozès. Aktinono poveikis dar mažesnis. Todèl šiame straipsnyje visas dèmesys yra skiriamas Rn-222, toliau vadinamam radonu.

Radonas kvejpuojant patenka i plaučius. Jam skylant susidaro radioaktyviụjų radono dukterinių produktų grandinè. Didžiausias apšvitos dozes lemia Po-218 (istoriškai susiklostęs pavadinimas - radis A, arba $\mathrm{RaA}$,), Pb-214 (RaB) ir Bi-214 (RaC). Šie radionuklidai turi trumpas pusejjimo trukmes (nuo kelių iki keliasdešimties minučių), todèl bendra visos ju grandinès pusėjimo trukmé yra apie pusé valandos. Dukteriniai radono skilimo produktai, paprastai būdami ant aerozolio dalelių, patenka i bronchus, nusèda ant jų epitelio ir skildami ji švitina. Turint galvoje, kad didelę jų jonizuojančiosios spinduliuotes dalị sudaro alfa dalelès, darosi aišku, kad apšvitos dozé, sąlygojama radono skilimo produktų, bus gana didelè. Nustatyta [1], kad pusę bendros metinès apšvitos efektinès dozès, kuri yra apie $2 \mathrm{mSv}$, žmogus gauna del radono ir jo skilimo produktų.

Radonas i pastatus patenka iš grunto po statiniu, statybinių medžiagų, vandentiekio vandens, atmosferos ir gamtinių dujų.

Radono šaltinis yra radis $\mathrm{Ra}-226$, kurio yra visuose aplinkos objektuose. Todèl radonas emanuoja iš grunto, statybinių medžiagų, gruntinio vandens ir gamtinių dujų. 1 lentelèje pateikti duomenys apie radionuklidų $\mathrm{Ra}-226$ ir $\mathrm{Ra}-228$ savitaji aktyvumą labiausiai paplitusiose uolienose [2].

Iš 1 lentelès duomenų matyti, kad savitasis radžio aktyvumas tos pačios rūšies uolienoje gali būti labai skirtingas, todèl, žinant tik grunto sudètị, tiksliai numatyti radžio kiekiu šiose uolienose neįmanoma. Tačiau net ir žinant radžio kieki grunte, radono išsiskyrimo iš grunto intensyvumo numatyti pakankamai tiksliai negalima, nes tai priklauso dar ir nuo daugelio kitu faktorių. Pavyzdžiui, esant žemesniam negu atmosferos oro slègiui uždarose statinių patalpose, radono emanacija iš grunto ir jo patekimas i pastato vidy suintensyveja ("kamino", angliškai "stack", efektas).

Radono tūrinius aktyvumus grunto ore sąlygoja radžio kiekiai grunte, radono emanacijos greitis ir grunto struktūra. Emanacijos esmę nusako tai, kad skylant nestabiliesiems branduoliams, išsiskiria palyginti dideli energijos kiekiai. Skylant radžiui, viena 
1 lentelè. Savitasis Ra-226 ir Ra-228 aktyvumas kai kuriose uolienose [2]

Table 1. Concentrations of Ra-226 and Ra-228 in some rocks [2]

\begin{tabular}{|l|l|c|c|c|c|}
\hline \multirow{2}{*}{ Uolienos tipas } & \multirow{2}{*}{ Pavyzdys } & \multicolumn{4}{c|}{ Savitasis aktyvumas, Bq/kg } \\
\cline { 3 - 6 } & & \multicolumn{2}{|c|}{ Ra-226 } & \multicolumn{2}{c|}{ Ra-228 } \\
\cline { 3 - 6 } & & vidurkis & intervalas & vidurkis & intervalas \\
\hline Rūgščios kilmès & Granitas & 78 & $1-370$ & 111 & $0,4-1030$ \\
Bazinès kilmès & Bazaltas & 11 & $0,4-41$ & 10 & $0,2-36$ \\
Nuosèdinès kilmès & Klintis & 45 & $0,4-340$ & 60 & $0,1-540$ \\
Suirusios, nuosedinès kilmès & Molis, smiltainis & 60 & $1-990$ & 50 & $0,8-1470$ \\
Vulkaninès kilmès & Gneisas & 50 & $1-1800$ & 60 & $0,4-420$ \\
Metamorfinès nuoseddos & Skalūnas & 37 & $1-660$ & 49 & $0,4-370$ \\
\hline
\end{tabular}

dalis išsiskiriančios energijos tenka alfa dalelèms, o kita - radono atomams. Šios energijos pakanka, kad atšokę radono atomai ịveiktų kristalinio lauko potencialini barjerą ir patekty ì kietosios dalelès aplinką (pavyzdžiui, ị grunto poras). Dalelès išorèje judantys radono atomai dar turi tam tikrą kinetinę energiją ir priklausomai nuo grunto makrostruktüros ir šios energijos gali implantuotis i greta esančią dalelę, patekti i gruntinị vandeni arba ị atvirą grunto porą. Pastaruoju atveju tikimybè radono atomui patekti $\dot{i}$ grunto paviršių, o kartu ir i statinių vidų, yra didžiausia. Radono emanacijos koeficientas, nusakantis, kokia dalis radono atomų patenka i grunto orą, paprastai neviršija dešimties procentu.

Radžio tūriniai aktyvumai grunte, grunto laidumas, radono emanacijos laipsnis lemia radono riziką tikimybę, kad ant tokio grunto pastatytame pastate radono tūriniai aktyvumai bus dideli. 2 lentelèje

2 lentelè. Grunto klasifikacija pagal radono riziką [3]

Table 2. Classification of soil by radon risk [3]

\begin{tabular}{|l|l|}
\hline $\begin{array}{c}\text { Rizikos } \\
\text { laipsnis }\end{array}$ & \multicolumn{1}{|c|}{ Grunto tipas } \\
\hline Didelis & $\begin{array}{l}\text { Uolienos ir dirvožemis, kuriuose yra } \\
\text { dideli radžio kiekiai (urano turtingas } \\
\text { granitas, molingasis skalünas), } \\
\text { dirvožemiai, turintys didelę radono } \\
\text { emanacijos laipsni (žvyras, molingasis } \\
\text { molis) }\end{array}$ \\
\hline Vidutinis & $\begin{array}{l}\text { Gruntai, turintys vidutinius radžio } \\
\text { kiekius - apie 25-50 Bq/kg (gneisas, } \\
\text { skalūninis molis) }\end{array}$ \\
\hline Mažas & $\begin{array}{l}\text { Gruntai, turintys mažus radžio kiekius } \\
\text { (klintis, dolomitas, bazinès vulkaninè } \\
\text { kilmès uolienos), gruntai, pasižymintys } \\
\text { mažu laidumu (molis, dumblas) }\end{array}$ \\
\hline
\end{tabular}

pateikta grunto klasifikacija pagal radono rizikos laipsnị [3], naudojama Švedijoje.

Maksimalūs radono tūriniai aktyvumai grunto ore gali būti apskaičiuoti taip:

$$
C_{\max }=A e \delta[(1-p) / p]
$$

čia $C_{m a x}$ - maksimalus radono tūrinis aktyvumas izoliuotos grunto poros ore $\left(\mathrm{Bq} / \mathrm{m}^{3}\right), A$ - radžio savitasis aktyvumas grunte $(\mathrm{Bq} / \mathrm{kg}), e$ - radono emanacijos koeficientas, $\delta$ - matricos, kurioje yra radis, tankis $\left(\mathrm{kg} / \mathrm{m}^{3}\right), p$ - šios matricos poringumas $(e \leq p)$. Pavyzdžiui, jeigu radžio savitasis aktyvumas lygus $12 \mathrm{~Bq} / \mathrm{kg}$, radono tūrinis aktyvumas grunto ore bus apie $20 \mathrm{kBq} / \mathrm{m}^{3}$.

Jungtinèse Amerikos Valstijose radono rizikos laipsniui nusakyti naudojamasi Jokelio ir Tannerio [4] pasiūlytu indeksu $Y$, kuris įvertina radono tūrinius aktyvumus patalpose, palyginti su JAV nustatytu baziniu lygiu $\left(150 \mathrm{~Bq} / \mathrm{m}^{3}\right)$ :

$$
Y=6,60 \cdot C_{\max }(k \cdot n)^{1 / 2} E F I \cdot E F 2 \cdot E F 3,
$$

čia $C_{\max }$ - maksimalus galimas radono tūrinis aktyvumas patalpose tam tikroje vietoje $\left(\mathrm{Bq} / \mathrm{m}^{3}\right), k-$ sausujų duju skvarbumo koeficientas $\left(\mathrm{m}^{2}\right), n$ - grunto poringumas, $E F 1, E F 2$ ir $E F 3$ - aplinkos faktoriai (EF1 priklauso nuo drenažo sąlygu, $E F 2$ - nuo gruntinio vandens būklès, $E F 3$ - nuo nepalankių aplinkos sąlygu, pvz. vejo, šalto klimato ir kt.).

Čekijoje radono programoje [5], ivertinant radono rizikos laipsni, remiamasi dviem pagrindiniais parametrais: išmatuotu radono kiekiu grunto ore ir grunto laidumo koeficientu. Grunto laidumui jivertinti naudojama grunto granuliometrinè analizè. Radono rizikos klasifikacija, naudojama Čekijoje, pateikta 3 lenteleje. 
3 lentelè. Radono rizikos klasifikacija [5]

Table 3. Classification of radon risk [5]

\begin{tabular}{|l|c|c|c|}
\hline \multirow{2}{*}{$\begin{array}{l}\text { Radono } \\
\text { rizikos }\end{array}$} & \multicolumn{3}{|c|}{$\begin{array}{c}\text { Radono Rn-222 tūrinis aktyvumas grunto } \\
\text { ore, } \mathrm{kBq} / \mathrm{m}^{3}\end{array}$} \\
\cline { 2 - 4 } & \multicolumn{3}{|c|}{ Grunto laidumas } \\
\cline { 2 - 4 } & Mažas & Vidutinis & Didelis \\
\hline Mažas & $<30$ & $<20$ & $<10$ \\
Vidutinis & $30-100$ & $20-70$ & $10-30$ \\
Didelis & $>100$ & $>70$ & $>30$ \\
\hline
\end{tabular}

Vokietijoje naudojama radono rizikos klasifikacija taip pat remiasi vietoje nustatytais radono tūriniais aktyvumais grunto ore ir trimis laidumo koeficiento $k$ klasemis. Remiantis šiais parametrais, sudarytos penkios radono rizikos grupès (4 lentelè).

4 lentelè. Radono rizikos klasifikacija, taikoma Vokietijoje [5]

Table 4. Radon risk classification used in Germany [5]

\begin{tabular}{|c|c|c|c|c|c|c|}
\hline & & \multicolumn{5}{|c|}{$\begin{array}{c}\text { Radono tūrinis aktyvumas grunto } \\
\text { ore } \mathrm{kBq} / \mathrm{m}^{3}\end{array}$} \\
\cline { 3 - 7 } $\begin{array}{c}\text { Laidumo } \\
\text { klasé }\end{array}$ & $\begin{array}{c}\text { Laidumas, } \\
\mathrm{m}^{2}\end{array}$ & $<10$ & $10-30$ & $30-100$ & $\begin{array}{c}100- \\
500\end{array}$ & $>500$ \\
\cline { 3 - 7 } & & \multicolumn{5}{|c|}{ rizikos grupe } \\
\hline 0 & $10^{-15}-10^{-14}$ & 1 & 1 & 2 & 3 & 6 \\
1 & $10^{-14}-10^{-12}$ & 1 & 2 & 3 & 4 & 6 \\
2 & $\leq 10^{-12}$ & 1 & 3 & 4 & 5 & 6 \\
\hline
\end{tabular}

\section{Tyrimu metodai ir rezultatai}

Siekiant nustatyti, kokią ịtaką radono tūriniams aktyvumams turi statybinès medžiagos, Radiacinès saugos centre nuolat atliekami statybinių medžiagu radionuklidinès sudèties tyrimai gama spektrometriniu metodu. Matavimams naudojamas Ge spektrometras (gamintojas - "Oxford"). Statybinių medžiagų bandiniai susmulkinami, išdžiovinami ir matuojamas juose esančiy radionuklidy aktyvumas. Kai kurių tyrimų rezultatai pateikti 5 lenteleje.

Kaip matyti iš šios lentelès duomenu, radžio savitieji aktyvumai minètose statybinèse medžiagose yra nedideli ir neviršija šalyje galiojančios higieninès normos HN 40-1994 didžiausių leistinų natūralios kilmès radionuklidụ aktyvumu pirmos klasès statybinèse medžiagose (naudotinose visur be apribojimų). Taigi statybinès medžiagos nèra radono tūrinius aktyvumus patalpose lemiantis veiksnys.
5 lentelè. Natūralios kilmès radionuklidu savitieji aktyvumai kai kuriose Lietuvoje gaminamose ir naudojamose statybinèse medžiagose

Table 5. Concentrations of natural radionuclides in some building materials used or manufactured in Lithuania

\begin{tabular}{|l|c|c|}
\hline \multicolumn{1}{|c|}{$\begin{array}{c}\text { Statybinè medžiaga, } \\
\text { gamintojas }\end{array}$} & \multicolumn{2}{|c|}{$\begin{array}{c}\text { Savitasis aktyvumas, } \\
\text { Bq/kg }\end{array}$} \\
\cline { 2 - 3 } & Ra-226 & Th-232 \\
\hline Cementas, Akmenè & $51-58$ & $17-23$ \\
Cementas, Kunda Nordic & $22-46$ & $19-33$ \\
Cementas, Krivoj Rogas & $40-50$ & $25-34$ \\
Plytos, Taurage & $38-52$ & $51-77$ \\
Silikatines plytos, Kupiškis & $11-15$ & $14-17$ \\
Silikatinès plytos, Vilnius & $9-11$ & $9-11$ \\
Sienu plokštès, Palemonas & $16-31$ & $17-38$ \\
Granito skalda, Ukraina & $26-43$ & $50-77$ \\
\hline
\end{tabular}

Kartu nepavyko nustatyti faktų, kad mūsų šalyje toks veiksnys būtų vandentiekio vanduo ar gamtinés dujos.

Radonas dèl nedidelès savo pusèjimo trukmès grunto paviršių difuzijos būdu pasiekia daugiausia iš keliụ metru gylio. Tačiau dèl grunto nevienalytiškumo (geotektoniniai lūžiai, karstiniai reiškiniai) jis gali pasiekti paviršių ir iš gilesnių žemès sluoksnių, kuriuose radžio savitieji aktyvumai yra kur kas didesni negu paviršiuje. Todèl radono tūrinių aktyvumų matavimai grunto ore ir statiniu patalpose turi būti atliekami ne tik atsitiktinai parinktuose taškuose, bet ir ten, kur radonas dèl minètu priežasčiu gali lengviau patekti $i$ grunto paviršių, kartu ir i pastatus.

Lietuvos regionuose, kuriuose del geologiniu sąlygu galimi didesni radono tūriniai aktyvumai patalpose, buvo atlikti bandomieji natūralios kilmès radionuklidu, taip pat ir radono, aktyvumu matavimai. Tokie regionai, Lietuvos geologijos tarnybos duomenimis, yra pietuose, kur kristalinis pamatas, kuriame yra dideli Ra-226 aktyvumai, yra arčiausiai paviršiaus, vakaruose, kur viršutiniame grunto sluoksnyje galimi didesni Ra-226 aktyvumai, ir šiaurejje, kur radonas $i$ grunto paviršių lengviau patenka dèl karstinių reiškinių. Radono tūriniai aktyvumai grunto ore buvo matuojami portatyviniu prietaisu MARKUS 10 (GAMMADATA, Švedija). Matavimo metu grunto oras per vamzdžio pavidalo zondą iš $0,7-1,0 \mathrm{~m}$ gylio yra siurbiamas i matavimo kamerą. Priklausomai nuo grunto tankio siurbimo trukmé yra nuo $30 \mathrm{~s}$ iki $3 \mathrm{~min}$. Kartu buvo atliekami Th-232, U-238 ir K-40 savituju 
aktyvumy grunte matavimai. Pastarieji matavimai buvo atliekami daugiakanaliu portatyviniu gama spektrometru GR-256 ("Exploranium G.S. Limited", Kanada), ịkasus jo detektavimo bloką i $30 \mathrm{~cm}$ gylį. 6 lentelejje pateikti šiu matavimų metu gauti kai kurie rezultatai.

Iš 6 lentelès matyti, kad radono tūriniai aktyvumai grunto ore paprastai viršija $10 \mathrm{kBq} / \mathrm{m}^{3}$, o kai kur - net $100 \mathrm{kBq} / \mathrm{m}^{3}$. Pagal Švedijos Nacionalinio miestu planavimo ir statybos departamento rekomendacijas statiniai, esantys tokiose vietose, patenka $i$ antrają radono rizikos grupę ir turi tureti radono apsauginę konstrukciją. Kai kurios vietos Biržų ir Telšių rajonuose patenka ì pirmąją grupę, todẻl statiniuose turi būti radoną izoliuojanti konstrukcija. Tokių konstrukcijų realizavimo büdai aprašyti [6].

Kaip minèta, yra daug faktorių, nulemiančių radono tūrinius aktyvumus patalpose. Tai kanalų, kuriais grunto oras patenka $\mathfrak{i}$ statinị, dydis ir skaičius, temperatūrų ir slègių skirtumai lauke ir patalpoje, barometrinis slègis ir statinio ventiliacinès savybès. Todèl suprantama, kad kai kuriais atvejais radono tūriniai aktyvumai statiniuose, esančiuose kelių šimtų metrų atstumu vienas nuo kito, skiriasi apie dešimt kartų. Aišku, kad labai didelę svarbą turi tai, kaip bus parinkti pastatai, kuriuose bus atliekami matavimai, ir kaip jie bus atliekami.

6 lentelè. Gama spektrometrinių ir radono tūrinių aktyvumų grunto ore matavimų rezultatai

Table 6. The results of gamma spectrometric measurements of soil and measurements of radon concentrations in soil air

\begin{tabular}{|c|c|c|c|c|c|c|}
\hline \multirow[t]{2}{*}{$\begin{array}{l}\text { Rajonas, matavimo taško } \\
\text { geografinès koordinatès }\end{array}$} & \multirow[t]{2}{*}{ Gruntas } & \multirow{2}{*}{$\begin{array}{l}\text { Gama dozès, } \\
\text { sąlgotos grunte } \\
\text { esančiu } \\
\text { radionuklidų, } \\
\text { galia, } \mu \mathrm{R} / \mathrm{h}\end{array}$} & \multicolumn{3}{|c|}{$\begin{array}{l}\text { Savitasis aktyvumas, } \\
\mathrm{Bq} / \mathrm{kg}\end{array}$} & \multirow[t]{2}{*}{$\begin{array}{l}\mathrm{Rn}-222 \text { tūrinis } \\
\text { aktyvumas grunto } \\
\text { ore, } \mathrm{Bq} / \mathrm{m}^{3}\end{array}$} \\
\hline & & & $\mathrm{K}-40$ & Ra-226 & Th-228 & \\
\hline \multirow[t]{2}{*}{ Varénos, $24^{\prime \prime} 33^{\prime} 20^{\prime \prime}, 54^{\prime \prime} 14^{\prime} 40^{\prime \prime}$} & rupusis smèlis & 3,9 & 538 & 12,2 & 15,6 & 11 \\
\hline & smèlis & 2,9 & 422 & 3,0 & 13,5 & 5 \\
\hline Varènos, $24^{\prime \prime} 29^{\prime} 30^{\prime \prime}, 54^{\prime \prime} 07^{\prime} 40^{\prime \prime}$ & smelis & 3,1 & 461 & 5,3 & 13,5 & 6 \\
\hline \multirow[t]{2}{*}{ Varénos, $24^{\prime \prime} 22^{\prime} 00^{\prime}, 54^{\prime \prime} 00^{\prime} 20^{\prime \prime}$} & žvyras & 4,2 & 576 & 7,6 & 18,8 & 3 \\
\hline & smulkusis smèlis & 2,4 & 346 & 3,0 & 8,8 & 12 \\
\hline Lazdijų, $23^{\prime \prime} 45^{\prime} 30^{\prime \prime}, 54^{\prime \prime} 00^{\prime} 50^{\prime}$ & smulkusis smèlis & 4,2 & 557 & 10,6 & 18,8 & 20 \\
\hline Lazdijų, $23^{\prime \prime} 52^{\prime} 20^{\prime \prime}, 54^{\prime \prime} 10^{\prime} 10$ & rupusis žvyras & 5,5 & 672 & 20,5 & 28,8 & 15 \\
\hline Varènos, $24^{\prime \prime} 10^{\prime} 00^{\prime \prime}, 54^{\prime \prime} 09^{\prime} 10^{\prime \prime}$ & žvyras, gargždas & 5,5 & 653 & 18,2 & 28,8 & 36 \\
\hline Vilniaus, $25^{\prime \prime} 10^{\prime \prime} 40^{\prime \prime}, 54^{\prime \prime} 30^{\prime} 50$ & smèlis & 3,5 & 480 & 8,4 & 15,3 & 6 \\
\hline Vilniaus, $25^{\prime \prime} 10^{\prime} 00^{\prime \prime}, 54^{\prime \prime} 33^{\prime} 20^{\prime \prime}$ & smèlis, molis & 4,0 & 499 & 12,2 & 20,0 & 13 \\
\hline Biržц, $24^{\prime \prime} 47^{\prime} 40^{\prime \prime}, 56^{\prime \prime} 15^{\prime} 50^{\prime \prime}$ & smèlis, dumblas & 5,5 & 672 & 19,0 & 30,3 & 25 \\
\hline \multirow[t]{2}{*}{ Biržu, $24^{\prime \prime} 47^{\prime} 20^{\prime \prime}, 56^{\prime \prime} 14^{\prime} 20^{\prime \prime}$} & smulkusis smèlis & 5,3 & 634 & 19,0 & 26,0 & 36 \\
\hline & smèlis, molis & 5,5 & 710 & 13,8 & 28,3 & 35 \\
\hline Biržų, $24^{\prime \prime} 45^{\prime} 20^{\prime \prime}, 56^{\prime \prime} 15^{\prime} 10^{\prime \prime *}$ & molis, smèlis & 5,7 & 691 & 19,8 & 27,8 & 38 \\
\hline Biržų, $24^{\prime \prime} 45^{\prime} 00^{\prime \prime}, 56^{\prime \prime} 14^{\prime} 40^{\prime \prime}$ & smèlis, molis & 6,6 & 787 & 23,6 & 33,8 & 39 \\
\hline Šiaulių, $23^{\prime \prime} 21^{\prime} 00^{\prime \prime}, 55^{\prime \prime} 56^{\prime} 20^{\prime}$ & smulkusis smèlis & 4,2 & 557 & 11,4 & 17,8 & 5 \\
\hline \multirow[t]{2}{*}{ Telšių, $22^{\prime \prime} 07^{\prime} 40^{\prime \prime}, 55^{\prime \prime} 50^{\prime} 00^{\prime}$} & smulkusis smèlis & 6,0 & 672 & 20,5 & 31,3 & 103 \\
\hline & molis, smèlis & 7,0 & 787 & 26,6 & 36,0 & 96 \\
\hline Telšių, $22^{\prime \prime} 10^{\prime} 00^{\prime \prime}, 55^{\prime \prime} 50^{\prime} 10^{\prime \prime}$ & rupusis žvyras & 5,5 & 538 & 30,4 & 32,0 & 39 \\
\hline
\end{tabular}

"Kalva tarp karstiniu igriuvu, "* karstinè igriuvos dugnas. 
Norint nustatyti, kokia yra radono patalpose situacija Lietuvoje, buvo nutarta atlikti matavimus atsitiktinai parinktuose gyvenamuosiuose namuose. Šių matavimų rezultatai duotų galimybę padaryti išvadas apie vidutinius radono tūrinius aktyvumus mūsu šalyje. Statistikos departamento duomenimis, Lietuvoje yra apie 440 tūkst. atskirų namų, ir eksperimentų patikimumo sumetimais buvo nutarta radono tūrinius aktyvumus matuoti būtent tokiuose namuose, atsitiktinai parinkus 400 pastatų.

Matuota šildymo sezono metu, kada ventiliacijos įtaka radono tūriniams aktyvumams yra mažesné, dviejuose atskiruose žemiausiai esančiuose naudojamuose kambariuose. Matavimo trukmé - ne mažesnè kaip 3 savaitès. Radono tūriniai aktyvumai patalpose laikui bejgant gana smarkiai svyruoja, ir ilgesnis matavimo laikas duoda galimybę suvidurkinti šiuos aktyvumus. Matavimams naudojami JAV kompanijos "Rad Elec Inc" elektretai, kurių veikimo principas pagrịstas tuo, kad įelektrintos plokštelès (elektreto) potencialas mažeja, ant jos nusėdant radono skilimo produktams. Šis potencialo sumažejimas yra proporcingas radono tūriniams aktyvumams ir ekspozicijos trukmei, todèl nustatyti radono tūrinius aktyvumus patalpose šiuo metodu yra gana paprasta.

Atlikus radono tũrinių aktyvumų matavimus 400 atsitiktinai parinktų namụ visoje Lietuvoje ir maždaug 30 namụ Biržų rajone, kuriame yra intensyviausi karstiniai reiškiniai, nustatyta, kad aritmetinis radono tūrinių aktyvumų vidurkis atsitiktinai parinktuose pastatuose yra $55 \mathrm{~Bq} / \mathrm{m}^{3}$, o minètuose namuose Biržy rajone $-125 \mathrm{~Bq} / \mathrm{m}^{3}$. Akivazdu, kad karstinių reiškinių regionas radono patalpose atžvilgiu yra jdomus ir kartu keliantis nerimą. Maksimalus Lietuvoje užregistruotas radono tūrinis aktyvumas patalpose viršija $1800 \mathrm{~Bq} / \mathrm{m}^{3}$. Higienos normos (HN 40-1994) nurodo, kad leistini maksimalūs radono lygiai pastatytuose namuose yra $100 \mathrm{~Bq} / \mathrm{m}^{3}$, o statomuose $-50 \mathrm{~Bq} / \mathrm{m}^{3}$. Še lygiai buvo nustatyti tuo metu, kada duomenų apie radono tūrinius aktyvumus mūsų šalies namuose dar nebuvo. Remiantis radiacinès saugos optimizavimo principu ir Europos Sajungos rekomendacijomis, buvo nustatyti nauji radono tūrinių aktyvumu patalpose maksimalūs leistini lygiai. Nuo 1998 metų sausio 1 dienos galiojančioje higienos normoje HN73-1997 šie aktyvumai yra lygūs atitinkamai 400 ir $200 \mathrm{~Bq} / \mathrm{m}^{3}$.

Pagal Tarptautinès radiologinès apsaugos komisijos rekomendacijas minètas $55 \mathrm{~Bq} / \mathrm{m}^{3}$ tūrinis radono aktyvumas sąlygos $0,95 \mathrm{mSv}$ dozę per metus. Vadinasi, galima teigti, kad radonas ir mūsu šalyje yra labai svarbus faktorius, lemiantis aplinkos, kurioje mes praleidžiame apie $80 \%$ savo laiko, kokybę.

\section{Išvados}

Radonas patalpose Lietuvoje yra svarbus faktorius, lemiantis gyventojų apšvitos dozę. Kai kuriais atvejais ši dozè lygi dešimtims milisivertų. Pagrindinis radono šaltinis mūsų šalyje yra gruntas. Kai kuriose vietose radono tūriniai aktyvumai jame gali viršyti $100 \mathrm{kBq} / \mathrm{m}^{3}$. Taigi tos vietos gali büti laikomos radono rizikos zonomis, o statant jose pastatus, kad būtų išvengta dideliụ radono tūrinių aktyvumų, būtina atlikti detalius statybvietès tyrimus, t.y. nustatyti radono tūrinius aktyvumus grunto ore ir grunto laidumą.

Šio straipsnio autoriai nuoširdžiai dekkoja Švedijos Radiacines saugos institutui (SSI) ir asmeniškai Gustavui Åkerblomui už pagalbq rengiant ši darbą.

\section{Literatūra}

1. United Nations Scientific Committee on the Effects of Atomic Radiation. Exposures from natural radiation sources. Vienna: UNSCEAR, 1997. $60 \mathrm{p}$.

2. G. Akerblom. The use of air-borne radiometric and exploration survey data and techniques in radon risk mapping in Sweden // IAEA-TECDOC- 827. Application of uranium exploration data and techniques in environmental studies. Vienna: IAEA, 1993, p. 212-231.

3. G. Åkerblom. Ground radon - monitoring procedures in Sweden // Geoscientist, 4 (4), 1994, p.21-27.

4. F.Y. Yokel, A.B. Tanner. Site exploration for radon source potential // NISTIR Report 5135. New York: US Dept of Commerce, 1992, p. 115-127.

5. I. Barnet. Radon risk mapping and geological aspects // Proceedings of training course "Radon Indoor Risk and Remedial Actions". Stockholm: SSI, 1995, p. 160-169.

6. G. Akerblom, B. Clavensjo. The Radon Book. Measures against Radon. Stockholm: The Swedish Council for Building Research, 1994. 129 p.

Iteikta 19980326

\section{CONCENTRATIONS OF INDOOR AND SOIL RADON IN LITHUANIA}

\section{K. Gasiūnas, A. Mastauskas, G. Morkūnas}

S u m mary

Uranium and its daughters including Ra-226 are naturally present in the Earth's crust and other environmental bodies. During decay of Ra-226 radioactive noble gas radon is produced. This gas emanates to the atmosphere from solid matrixes containing Ra-226. It 
causes a special problem connected with the fact that radon accumulates in the closed spaces of buildings. Increased concentrations of radon indoors in many cases are the significant source of human exposure to ionizing radiation. Radon daughters having been deposited in the airways of human lungs are the source of alpha particles which irradiates the inner surface of airways. Since radiation quality of alpha radiation is high and small volumes of tissues are being irradiated, the influence of indoor radon as a source of ionizing radiation is significant.

In order to forecast indoor radon concentrations and to take necessary remedial (in existing buildings) or prevention (in new buildings) measures, the main sources of indoor radon should be known in each country or geographical region. It may be soil, building materials, water and natural gas. It has been determined that the main source of indoor radon in Lithuania is soil. Permanent investigations of radionuclide content of building materials used or manufactured in Lithuania have not revealed any building materials with concentrations of naturally occurring radionuclides exceeding maximum permitted levels determined by the Lithuanian Hygienic Standards HN 401994. These investigations are performed by means of gamma spectrometry using the Ge spectrometer by Oxford after sample grinding and drying.

A short review of radon risk mapping techniques used in Sweden, USA, Germany and Czech Republic is presented in paper. These techniques may be used for creation of similar technique in Lithuania with corrections connected with local geology. When determining radon risk mainly two parameters should be taken into account: radium content in soil (or radon content in soil air) which is associated with the type of soil and permeability of soil. The Lithuanian system of radon risk determination is not created yet because more detailed data on radon concentrations in soil air should be collected.

Data from field measurements of radon concentrations in soil air and concentrations of naturally occurring radionuclides are presented. These measurements were carried out in some potentially important from the point of view of radon risk regions of Lithuania. Concentrations of Ra-226, Th-228 and K-40 in soil have been measured by gamma spectrometer GR-256 by Exploranium on the surface layer (up to $30 \mathrm{~cm}$ ) of soil. Concentrations of radon in soil have been measured by MARKUS 10 in the depth of $70 \mathrm{~cm}$. The measurements have been performed directly without sampling and sample preparation by digging the detector of Exploranium and pumping rod of MARKUS 10 in the investigated soil. The results indicate that there are some regions in Lithuania with radon concentrations in soil air exceeding $100 \mathrm{kBq} / \mathrm{m}^{3}$. Though radon risk depends on soil permeability these results show that these areas may be identified as areas of medium or even high radon risk. The system for classification of building sites in terms of indoor radon risk should be created in Lithuania in order to follow requirements of Lithuanian radiation protection standards and to keep below determined action levels of indoor radon$400 \mathrm{~Bq} / \mathrm{m}^{3}$ in existing buildings and $200 \mathrm{~Bq} / \mathrm{m}^{3}$ in constructed ones.

Results of indoor radon measurements are presented as well. The measurements have been performed in 400 randomly selected detached houses during heating season in two lowest permanently used rooms. Duration of one measurement exceeds 3 weeks. E-PERM electrets have been used for this type of measurements. The results show that the average concentration of indoor radon in Lithuania is $55 \mathrm{~Bq} / \mathrm{m}^{3}$. In some cases these concentrations exceed the above-mentioned action levels and approach $2000 \mathrm{~Bq} / \mathrm{m}^{3}$. It shows that indoor radon problems exist in Lithuania as in many other countries. The average concentration of indoor radon in karst region is $125 \mathrm{~Bq} / \mathrm{m}^{3}$. It shows that special attention should be paid to such regions because conditions for increased intake of radon to buildings may exist.

Indoor radon is one of the main sources of exposure in Lithuania. In some cases it may be the essential source causing tens of milisieverts of annual effective dose. It shows that the problem of indoor radon is important in Lithuania.

Kęstutis GASIUUNAS. Physicist, PhD (deceased). Fields of activity in radiation protection: gamma spectrometric and indoor radon measurements, investigations of radon in soil gas, determination of relationships of indoor and soil radon concentrations.

Albinas MASTAUSKAS. Director of Radiation Protection Centre, Kalvariju 153, Vilnius, Lithuania. Author and coauthor of publications on radiation protection legislation and infrastructure, dose assessment, influence of radiation on human organism.

Gendrutis MORKūNAS. Engineer radiologist. Radiation Protection Centre. Trainee-investigator, junior researcher, assistant at the Institute of Physics (1983-95). Research interests: radioactive noble gases, including indoor radon, radioecology, Chernobyl consequences in Lithuania, radiation protection. 